Adam Wójcik

Uniwersytet Wrocławski e-mail: 300111@uwr.edu.pl

\title{
Orędzie biskupów polskich do biskupów niemieckich jako krok do unormowania stosunków polsko-niemieckich
}

\begin{abstract}
ABSTRAKT
Kwestia pojednania polsko-niemieckiego po 1945 r. oraz działania podejmowane przez obie strony, w celu osiągnięcia nici porozumienia, niewątpliwie powiązane są z działaniami Kościoła katolickiego w Polsce i kierującego nim kardynała Stefana Wyszyńskiego. Orędzie biskupów polskich do biskupów niemieckich jest symbolem przebaczenia i chęcią odbudowy relacji pomiędzy narodem polskim i niemieckim. Krok, jaki wykonali zwierzchnicy Kościoła w Polsce wobec strony niemieckiej przyczynił się do unormowania, a z czasem do podjęcia wzajemnych stosunków polsko-niemieckich. Celem pracy jest ukazanie istoty Orędzia biskupów polskich oraz ukazanie reakcji obydwu stron na działania podjęte przez hierarchów kościelnych. W pracy dość szczegółowo przedstawione są relacje polsko-niemieckie przed publikacją Orędzia biskupów polskich do biskupów niemieckich, a także sytuacja po publikacji listu. Artykuł przedstawia chronologicznie proces przygotowania listu, oraz idee, jakie przyświecały autorom przełomowego dzieła, a także z jakimi problemami po publikacji Orędzia musiał się zmierzyć Kościół katolicki w Polsce ijego kierownictwo. Ukazane zostały również działania propagandowei antykościelne, mające zniszczyć zaufanie ludzi do Kościoła i kard. Stefana Wyszyńskiego. Praca pokazuje jak ważnym momentem w dziejach relacji polsko-niemieckich jest publikacja Orędzia biskupów polskich, która to stała się podwaliną poprawy, a z czasem także i nawiązaniem stosunków międzysąsiedzkich. Praca opisuje temat wielokrotnie poruszany przez innych autorów, lecz zawiera nowe, powstałe z biegiem lat informacje dotyczące istoty tego ważnego dzieła.
\end{abstract}




\section{ABSTRACT \\ Letter of Reconciliation of the Polish Bishops to the German Bishops as a Step Towards Normalizing Polish-German Relations}

The issue of Polish-German reconciliation after 1945 and the actions of both parties to reach an agreement are undoubtedly related to the activities of the Catholic Church in Poland and of Cardinal Stefan Wyszyński, who led it. Letter of Reconciliation of the Polish Bishops to the German Bishops is a symbol of forgiveness and the will to rebuild relations between the Polish and German nations. The step taken by the leaders of the Church in Poland towards the German side contributed to the normalization and, with time, of establishing mutual Polish-German relations. The aim of the work is to show the essence of the Polish bishops letter and showing the reaction of both sides to the actions taken by the church hierarchs. At work, Polish-German relations are quite fast before the publication of the Polish Orbis to German bishops, as well as the situation after the publication of the letter. The article presents the process of preparing the letter in chronological order, as well as the ideas that guided the authors of the breakthrough work. The article presents what problems after the publication of Lub, the Catholic Church in Poland and its leadership had to face. There were also shown responses to propaganda and anti-church trust in people towards the Church and Cardinal Stefan Wyszyński. The work shows how important a moment in the history of Polish-German relations is the publication of the letter of the Polish bishops, which is to become the basis for the improvement and, over time, the establishment of relations between neighbors. The work describes a topic repeatedly raised by other authors, but contains new information, developed over the years, about the essence of this important work.

Słowa kluczowe: Orędzie biskupów polskich do biskupów niemieckich, relacje polsko-niemieckie, kard. Stefan Wyszyński, abp Bolesław Kominek

Key words: Letter of Reconciliation of the Polish Bishops to the German Bishops, Polish-German relations, cardinal Stefan Wyszyński, Bolesław Kominek

\section{Krok w stronę unormowania wzajemnych stosunków}

Orędzie biskupów polskich do biskupów niemieckich jest uważane za jeden $\mathrm{z}$ najważniejszych, a z pewnością przełomowy moment w powojennej historii pojednania polsko-niemieckiego. Zawiera ono przypomnienie historycznych relacji omiędzy narodem polskim a narodem niemieckim, a także bardzo rzadko w tamtym okresie spotykane stwierdzenie, że okres wojenny przyniósł także cierpienie dla Niemców. Wskazano tu m.in. na cierpienia Niemców spowodowane przesiedleniami za zachodnią stronę Odry i Nysy Łużyckiej oraz 
poruszono temat braku akceptacji przez Niemców nowej granicy państwa polskiego na Odrze i Nysie Łużyckiej.

List biskupów polskich do ich niemieckich odpowiedników jest pierwszym tak poważnym krokiem w stronę polepszenia, a z czasem i unormowania wzajemnych relacji w stosunkach polsko-niemieckich. Orędzie biskupów polskich do biskupów niemieckich jest orędziem pokoju i podwaliną pod fundament nowych relacji między zwaśnionymi narodami. Decyzja o podjęciu tak nietypowego kroku w stronę powszechnie uznawanych wrogów, wiązała się z niezwykłą odwagą najwyższych hierarchów kościelnych oraz wiarą w lepsze czasy, w których najbliżsi sąsiedzi nie będą do siebie pałać nienawiścią. Ten, jakże istotny krok do pojednania spotkał się zarówno z aprobatą części społeczeństwa polskiego i niemieckiego, jak również z kompletną dezaprobatą pozostałej części społeczeństwa polskiego, na czele z władzami najwyższymi Polskiej Zjednoczonej Partii Robotniczej. Negatywnie podsumowany przez partyjną propagandę list wywołał niemałe poruszenie, oburzenie i niezadowolenie społeczeństwa polskiego, które przeżyło okres okupacji niemieckiej i bardzo dobrze pamiętało zbrodnie, jakich dopuszczali się niemieccy agresorzy. List biskupów polskich do niemieckich braci w Chrystusie, wbrew powszechnie głoszonej propagandzie partyjnej zawierał dokładne przypomnienie krzywd i zbrodni dokonanych przez naród niemiecki, na narodzie polskim w okresie okupacji, jak również na przestrzeni dziejów.

\section{Relacje polsko-niemieckie w latach 1945-1965}

Stosunki polsko-niemieckie nigdy nie należały do najlepszych. Rozbiory Polski, germanizacja ludności polskiej, hamowanie polskiego rozwoju gospodarczego po I wojnie światowej, agresja zbrojna we wrześniu 1939 r. oraz zbrodnicza działalność niemiecka w czasie II wojny światowej, przyczyniły się do tego, iż ludność polska postrzegała Niemców jako zło wcielone. Wraz z ustanowieniem zachodniej granicy państwa polskiego na linii Odry i Nysy Łużyckiej na terenach Polski znalazła się ludność niemiecka, mieszkająca na tych terenach od pokoleń. Nowe polskie władze podkreślały przy każdej możliwej okazji, że na nowo wcielonych ziemiach zamieszkuje również ludność polska, czego przykładem jest funkcjonujący przed wybuchem wojny Konsulat Rzeczpospolitej Polskiej we Wrocławiu ${ }^{1}$. Działał także Dom Polski, a także rzymskokatolicka wspólnota zgromadzona przy kościele pw. św. Marcina na Ostrowie Tumskim². Podstawowym problemem powstałym na nowo przyłączonych ziemiach była żyjąca tu ludność niemiecka, dla której nie było miejsca w nowej powojennej demokracji ludowej. Na skutek działań okupacyjnych ludność darzyła Niemców szczerą nienawiścią i chęcią zemsty za wyrządzone krzywdy. Uważano

1 R. Gelles, Konsulaty we Wrocławiu, Wrocław 1996, s. 144.

2 Z. Antkowiak, Wrocław od A do Z, Wrocław 1991, s. 153. 
w tamtym czasie, że Polacy i Niemcy nie mogą mieszkać i normalnie funkcjonować wspólnie, gdyż jest to po prostu niemożliwe. Powszechny był postulat wysiedlenia ludności niemieckiej zamieszkującej na wschód od Odry i Nysy Łużyckiej. Po raz pierwszy na poważnie projekt ten został poruszony w 1945 r., podczas konferencji w Poczdamie. Stanisław Jankowiak w swojej pracy Wysiedlenie i emigracja ludności niemieckiej $w$ polityce władz polskich w latach 1945-1970 wskazuje, iż Stalin postulował jak największe wysiedlenie Niemców z tzw. Ziem Odzyskanych, wizja ta spotkała się natomiast z dezaprobatą premiera Churchilla, miał on uważać, iż bardziej odpowiednie będzie wysiedlenie takiej samej liczby Niemców, co Polaków z ziem wcielonych do Związku Socjalistycznych Republik Radzieckich. Ostatecznie przedstawiciele Wielkiej Brytanii, Stanów Zjednoczonych i Związku Radzieckiego podjęli decyzję o wysiedleniu całej ludności niemieckiej zamieszkującej ziemie polskie. Władze najwyższe Polskiej Zjednoczonej Partii Robotniczej uznały, iż Polska Ludowa ma być państwem jednolitym narodowościowo, a występowanie mniejszości niemieckiej mogłoby powodować niepożądane reakcje ludności polskiej względem niemieckiej jak i wzajemnie. Podjęta przez Komitet Centralny Polskiej Partii Robotniczej Uchwała z dnia 16 maja 1945 r. wskazywała konieczność wysiedlenia ludności niemieckiej w ciągu roku $\mathrm{z}$ terenów polskich i osiedlenia $\mathrm{w}$ ich miejsce około 3,5 miliona osadników ze wschodu ${ }^{3}$. Parę miesięcy później dnia 20 listopada $1945 \mathrm{r}$. Rada Kontroli będąca najwyższym organem sojuszniczym w okupowanych Niemczech, zatwierdziła plan transferu ludności niemieckiej z terenów Austrii, Czechosłowacji, Węgier oraz Polski. Co do Niemców mieszkających na ziemiach austriackich Rada ustaliła, iż będą musieli opuścić ją ci, którzy przybyli do Austrii wraz z wcieleniem (Ansschluss) tego państwa w 1938 r. w granice III Rzeszy ${ }^{4}$. Według planu transferowego z Polski miało zostać wywiezionych około 3,5 miliona Niemców ${ }^{5}$. Po zakończeniu II wojny światowej pozbywanie się niechcianych mieszkańców pochodzenia niemieckiego odbywało się na dwa sposoby. Pierwszym były zorganizowane wysiedlenia Niemców na zachód, natomiast drugim sposobem było tworzenie warunków skłaniających Niemców do wyjazdu ${ }^{6}$. Faktyczną realizację pierwszego sposobu powierzono wojsku ${ }^{7}$. Drugi sposób był realizowany przez propagandę i ludność cywilną, która pamiętając piekło okupacji uprzykrzała życie niemieckiej społeczności w każdy możliwy sposób ${ }^{8}$. Należy również wspomnieć,

3 S. Dudra S., B. Nitschke (red.), Mniejszości narodowe i etniczne w Polsce po II wojnie światowej, Kraków 2010, s. 37..

4 K. Skubiszewski, Wysiedlenie Niemców po II wojnie światowej, Warszawa 1968, s. 111.

5 Ibidem, s. 112.

6 S. Jankowiak, Wysiedlenia Niemców z Polski po II wojnie światowej, „Pamięć i Sprawiedliwość” 2004, nr 2(6), s. 144, 148.

7 P. Kacprzak, Polityka władz polskich wobec ludności niemieckiej w okresie funkcjonowania Ministerstwa Ziem Odzyskanych, „Czasopismo Prawno-Historyczne” 2010, t. 62, z. 2, s. 217. Ibidem. 
iż w okresie powojennym niechęć i represje były także stosowane wobec Polaków, którzy w okresie wojny wyrzekli się swego pochodzenia i przyjęli obywatelstwo agresora. Byli oni uznawani za zdrajców i najgorszy sort społeczny w powojennej rzeczywistości. Uchwała Całej Izby Karnej Sądu Najwyższego z dnia 2 czerwca 1945 r. (K.11/45), stwierdzała, iż fakt zgłoszenia przez obywatela polskiego w czasie wojny swej przynależności do narodowości niemieckiej jest działaniem na korzyść nieprzyjaciela. Działanie na korzyść okupanta było utożsamiane jako jednanie się z wrogiem i zdrada narodu. Kolejnym przykładem działań państwowych wobec zdrajców był wydany 28 czerwca 1946 r. dekret o odpowiedzialności karnej za odstępstwo od narodowości w czasie wojny 1939-1945 r. Zgodnie z art. 1 tegoż dekretu, obywatel polski, który zgłosił swoją przynależność do narodowości niemieckiej lub uprzywilejowanej w okresie II wojny światowej podlega odpowiedzialności karnej. Kara za zmianę obywatelstwa polskiego na obywatelstwo niemieckiego okupanta wynosiła od roku do 10 lat pozbawienia wolności. Naród niemiecki i zdrajców ojczyzny piętnowano przez prasę, radio, plakaty propagandowe. Poruszając problematykę stosunków polsko-niemieckich w latach 1945-1965 warto wspomnieć również o oficjalnych relacjach pomiędzy państwami niemieckimi a Polską Ludową. Relacje te były dość zróżnicowane i specyficzne. Powojenna polityka Polskiej Rzeczpospolitej Ludowej oraz niemieckiej Republiki Demokratycznej była nieodzownie związana z polityką Związku Radzieckiego. Obydwa te państwa znalazły się właśnie $\mathrm{w}$ powojennej strefie wpływów ZSRR, co wiązało się z tym, iż ich wzajemne relacje muszą ulec zmianie. Niemców z NRD przedstawiano jako tych, w żaden sposób niepowiązanych ze zbrodniczą działalnością narodowego socjalizmu. Niemców przedstawiano z reguły w najgorszym świetle, lecz wspominano także, iż istnieją przyzwoici Niemcy ${ }^{9}$. Utożsamiano ich jako przeciwników polityki Adolfa Hitlera, a także zdarzało się wspomnieć o niemieckiej działalności antyhitlerowskiej. Częściej jednak tematu Niemców starano się nie poruszać. Działania propagandowe mające na celu przemilczenie odpowiedzialności historycznej Niemców z NRD były mało przekonujące dla ludności polskiej. Byli to ci sami Niemcy, którzy wraz z powstaniem w 1949 r. NRD stali się jego nową społecznością. Ludność polska, a także kierownictwo partii traktowali Niemców jak najgorsze zło świata. Propaganda partyjna pokazywała Niemców zawsze w złym świetle, a także próbowała pokazywać zwycięstwa Polaków nad Niemcami ${ }^{10}$. Miało to na celu zarówno wzbudzić większą niechęć do sąsiedniego narodu, jak również podnieść Polaków na duchu. Sowieci próbowali na siłę przybliżyć Polskę i NRD do siebie w celu współpracy socjalistycznych państw. Przykładem

9 A. Dudek, Wybrane czynniki historyczne wptywające na politykę władz PRL, [w:] Polityka czy propaganda. PRL wobec historii, red. P. Skibiński, T. Wiścicki, Warszawa 2009, s. 21.

10 Ibidem, s. 22. 
działań mających przybliżyć do siebie te dwa państwa było uznanie w $1950 \mathrm{r}$. granic na Odrze i Nysie Łużyckiej oraz oficjalne podpisanie traktatu w Zgorzel$\mathrm{cu}^{11}$. Przez lata władze Niemieckiej Republiki Demokratycznej stopniowo wyzbywały się praw i roszczeń do ziem i majątków pozostawionych na wschodzie, w zamian za ucieczkę od historycznej odpowiedzialności za okres II wojny światowej ${ }^{12}$. Warto wspomnieć, iż NRD potrzebowała Polski jako pewnego rodzaju orędowniczki swoich działań i partnera na arenie międzynarodowej. Spowodowane to było izolacją dyplomatyczną NRD aż do lat 70. XX w. W oczach świata to RFN był przedstawicielem państwa niemieckiego na arenie międzynarodowej, a NRD było utożsamiane z państwem satelickim ZSRR. Pomimo wzajemnej niechęci do siebie, zarówno Polska Ludowa jak i NRD będące w ,,cieniu wielkiego brata" zmuszone były do utrzymywania wzajemnych stosunków, choćby tylko pozornych ${ }^{13}$. Stosunki między Polską Ludową a Republiką Federalną Niemiec aż do 1972 r. istniały jedynie na płaszczyźnie gospodarczo-handlowej. Przed 1972 r. PRL oraz RFN nie nawiązywały żadnych stosunków dyplomatyczno-konsularnych. Polska jako państwo bloku wschodniego uważała, że Republika Federalna Niemiec nie chce pogodzić się z utratą części terytorium niemieckiego na korzyść Polski oraz że nie uzna postanowień poczdamskich. Niemcy Federalne uważały natomiast, że Polska nie jest ani niepodległym ani samodzielnym państwem, a jedynie satelitą Związku Radzieckiego. Relacje pomiędzy tymi państwami można śmiało określić jako negatywne, choć przez pewien czas wcale nie istniały. Przykładem na to jest dziesięcioletni okres braku jakichkolwiek oficjalnych działań skierowanych w stronę PRL bądź RFN w latach 1945-1955. Po dziesięcioletniej ciszy we wzajemnych relacjach Uchwałą Rady Państwa $\mathrm{z}$ dnia 18 lutego $1955 \mathrm{r}$. oficjalnie strona polska poinformowała o zakończeniu stanu wojny z Niemcami ${ }^{14}$. W 1957 r. przejawiano chęć nawiązania stosunków dyplomatycznych między PRL a RFN, lecz wycofano się z tego pomysłu. Prawdopodobnie do nawiązania stosunków nie doszło ze względu na uznawanie przez rząd PRL Niemieckiej Republiki Demokratycznej jako państwa. Faktu tego nie mógł zaakceptować rząd w Bonn, ponieważ Niemcy Zachodnie nie uznawały podziału Niemiec ${ }^{15}$. Polityka Polski Ludowej i Niemieckiej Republiki Demokratycznej wobec RFN zbliżyła się do siebie po wzniesieniu muru berlińskiego. Owe zbliżenie spowodowane było wspólnymi planami wobec RFN. Planami

11 A. Kotula (red.), Przyjaźń nakazana? Stosunki między NRD i Polską w latach 1949-1990, Szczecin 2003, s. 40.

12 Ibidem.

13 Ibidem, s. 41.

14 H.A. Jacobsen, M. Tomala, Warszawa-Bonn 1945-1991. Stosunki polsko-niemieckie. Analiza i Dokumenty, Warszawa 1992, s. 27.

15 W. Borodziej (red.), Polska wobec zjednoczenia Niemiec 1989-1991, Warszawa 2006, s. 8. 
tymi było uznanie przez RFN granicy na Odrze i Nysie Łużyckiej, a także uznanie przez rząd w Bonn NRD jako państwa.

\section{Orędzie biskupów polskich do niemieckich braci w Chrystusie}

Dnia 11 października 1962 r. papież Jan XXIII uroczyście otworzył Sobór Watykański II. Sobór odbywał się pod hasłem odnowy Kościoła (aggiornamento $)^{16}$.Poruszono na nim sprawy dotyczące liturgii, prawa kanonicznego, czy wzajemnych relacji kościelnych. Pośród licznych delegacji z całego świata w Watykanie znalazła się również delegacja Episkopatu Polski, którą łącznie przez cały okres trwania Soboru Watykańskiego II reprezentowało 66 hierarchów kościelnych. Warto wspomnieć, że podczas inauguracji Soboru Watykańskiego II naszą ojczyznę reprezentowało 24 polskich biskupów. Przez cały okres trwania Soboru jedynie dziewięciu hierarchów było obecnych na wszystkich jego sesjach ${ }^{17}$ : kard. Stefan Wyszyński, abp Karol Wojtyła, abp Antoni Baraniak, bp Piotr Kołwa, bp Michał Klepacz, bp Kazimierz Kowalski, bp Antoni Pawłowski, bp Herbert Bednarz oraz bp Franciszek Jop reprezentowali naszą ojczyznę na wszystkich sesjach Soboru Watykańskiego II. Delegacją hierarchów kościelnych z Polski kierował kard. Stefan Wyszyński, któremu władze komunistyczne wielokrotnie odmawiały wydania paszportu. W obawie przed międzynarodowym skandalem, związanym $\mathrm{z}$ brakiem jednego $\mathrm{z}$ najważniejszych hierarchów kościelnych ówczesnych czasów na sesjach soborowych, partia zezwoliła na wyjazd Wyszyńskiego do Watykanu ${ }^{18}$. Sobór Watykański II przyniósł Kościołowi wiele istotnych i cennych refleksji oraz działań faktycznych. Jednym z nich był właśnie list polskich biskupów skierowany do biskupów niemieckich. Był on pewnego rodzaju uwieńczeniem rozmów kard. Stefana Wyszyńskiego z kard. Juliusem Dopfnerem, który w ówczesnych czasach przewodził Konferencji Episkopatu Niemiec. Po raz pierwszy do spotkania kardynałów doszło w bazylice na Zatybrzu, gdzie wspólnie modlili się przed grobem bp. Hozjusza. Wracając bezpośrednio do tematu Orędzia to jeszcze przed otwarciem Soboru powstał projekt dokumentu, który podejmował próbę oceny systemu komunistycznego. Prace nad dokumentem były koordynowane przez kard. Alfreda Ottawianiego. W pracach nad owym dokumentem uczestniczył za zgodą Prymasa Wyszyńskiego rezydujący w Rzymie, polski abp Józef Gawlina. Publikacja dokumentu nie doszła do skutku, a prace nad nim zostały przerwane przez Stefana Wyszyńskiego i Juliusa Dopfnera ${ }^{19}$. Przerwanie prac spowodowane było

\footnotetext{
16 E.K. Czaczkowska, Kardynał Wyszyński. Biografia, Kraków 2013, s. 499.

17 Ibidem, s. 500.

18 Ibidem.

19 Ibidem, s. 511.
} 
obawą przed pogorszeniem położenia pozycji Kościoła w PRL i NRD. Wiadomo, że przedstawiciele władz kościelnych byli nieustannie inwigilowani. Sobór Watykański II był obserwowany przez różne agencje wywiadowcze państw świata, a szczególnie pracom soborowym przyglądał się Komitet Bezpieczeństwa Państwowego ZSRR $(\mathrm{KGB})^{20}$. Polscy biskupi, kierując się wiekową mądrością Kościoła katolickiego wyrazili chęć wzajemnego pojednania się z narodem niemieckim. Biskupi polscy wiedzieli dobrze, że pielegnowanie urazy do Niemców nie tylko przekreśla możliwość podjęcia jakiejkolwiek relacji z zachodnim sąsiadem, ale także jest niezgodne z naukami Kościoła. W Ewangelii według św. Mateusza napisane jest „Bo jeśli odpuścicie ludziom ich przewinienia, odpuści i wam Ojciec wasz niebieski. A jeśli nie odpuścicie ludziom, i Ojciec wasz nie odpuści wam przewinień waszych" ${ }^{21}$. Ewangelia jasno daje do zrozumienia, że należy przebaczać, tak więc biskupi kierując się słowami Jezusa Chrystusa uznali, że pojednanie się z wrogiem będzie wypełnieniem słów Bożych, jak również krokiem w stronę zażegnania nienawiści i naprawy wzajemnych relacji. List biskupów polskich do biskupów niemieckich to jeden z 56 listów wysłanych do hierarchów kościelnych świata. Zawierały one zaproszenie przedstawicieli kościelnych na obchody Milenium Chrztu Polski, które odbyć się miały w 1966 r. Listy zostały skierowane do szerokiego grona odbiorców. Wśród nich znaleźli się papież Paweł VI, biskupi Anglii, Austrii, Belgii, Francji, Libanu, Szwajcarii, Stanów Zjednoczonych, Włoch, a także do Światowej Rady Kościołów w Genewie. Jeden $\mathrm{z}$ listów milenijnych trafił nawet do patriarchy Konstantynopola Atenagorasa. Pojawiła się także hipoteza, że jeden z listów milenijnych wysłany został także do Chin, a konkretniej mówiąc do biskupów Tajwanu ${ }^{22}$. Z listami milenijnymi związana jest także prośba Prymasa Wyszyńskiego, aby miejscowe episkopaty przez jeden dzień modliły się za Polskę. W tym miejscu należy wspomnieć, iż w odezwie na prośbę Prymasa w wielu państwa takich jak Argentyna, Stany Zjednoczone, Hiszpania czy Republika Południowej Afryki zorganizowane zostały modlitwy w intencji jego ojczyzny ${ }^{23}$. Orędzie skierowane do narodu niemieckiego zostało w całości spisane w języku niemieckim przez głównego inicjatora pojednania polsko-niemieckiego arcybiskupa wrocławskiego Bolesława Kominka. Podpisane zostało ono 18 listopada 1965 r. w Papieskim Instytucie Polskim przy via Pietro Cavallini 38 w Rzymie. Arcybiskup Bolesław Kominek przedłożył do podpisu biskupom uczestniczącym w czwartej i zarazem ostatniej sesji Soboru Watykańskiego II list w języku niemieckim, skierowany do hierarchów Kościoła w Niemczech. List sygnowało trzydziestu sześciu biskupów, począwszy w kolejności od kard. Wyszyńskiego, abp. Bolesława Kominka, abp. Karola

20 Ibidem, s. 526.

21 Ewangelia według św. Mateusza, 6,15-16.

22 M. Rajfur, Cały świat ustyszat, „Gość Niedzielny”, 29 listopada 2020, s. V.

23 Ibidem. 
Wojtyły i innych. Istotnym faktem jest to, że nie wszyscy wiedzieli co podpisują. Zdecydowana większość biskupów nie znała języka niemieckiego ${ }^{24}$. Biskup Bogdan Sikorski twierdził, iż nie wszyscy biskupi byli zadowoleni z inicjatywy pokojowej skierowanej w stronę niemiecką, lecz szacunek wobec osoby Prymasa Wyszyńskiego i jego powszechny autorytet spowodowały akceptację Orędzia przez najwyższych hierarchów kościelnych. Wiadomo dziś, że Stolica Apostolska była informowana szczegółowo o pracach nad listem oraz że wyraziła się pozytywnie na jego temat. Sam Paweł VI wspierał polskich biskupów, gdyż ich działania mogły polepszyć nie tylko stosunki między narodami, ale także sytuację Kościoła na wschód od Odry i Nysy Łużyckiej. Orędzie początkowo zostało błędnie dostarczone do rezydencji kard. Fringsa w Rzymie. W przeciągu paru dni list otrzymali już wszyscy adresaci ${ }^{25}$. Orędzie biskupów polskich do biskupów niemieckich zaczyna się od informacji i zaproszenia Niemców na obchody Tysiąclecia Chrztu Polski, które miały odbyć się na Jasnej Górze. Następnie w liście przedstawione zostały dzieje Polski od momentu przyjęcia przez Mieszka I chrztu w 966 r. do czasów ówczesnych. List uwzględniał także relacje między naszymi narodami na przestrzeni dziejów. Interesujący jest fakt, iż list biskupi wspomina także Niemców, których spotkały różnego rodzaju nieszczęścia podczas rządów NSDAP. Wymienia się tu nazwiska kardynałów Faulhabera, von Galena, Preysinga, a także bojowników ruchu antyhitlerowskiego. Ostatnia część listu zawiera najbardziej kontrowersyjne słowa ówczesnych czasów, które stały się symbolem pojednania polsko-niemieckiego. Słowami tymi są ,,... wyciągamy do was nasze dłonie z ław kończącego się Soboru, udzielamy przebaczenia i prosimy o przebaczenie".

\section{Reakcje na Orędzie biskupów polskich do biskupów niemieckich}

Orędzie polskich hierarchów Kościoła katolickiego wywołało niemałe poruszenie w opinii publicznej. Większość społeczeństwa wypowiadała się nieprzychylnie na temat Orędzia, lecz zdarzali się i tacy którzy popierali działania Prymasa i jego współpracowników. Głównymi krytykami listu biskupów polskich do ich niemieckich odpowiedników była Polska Zjednoczona Partia Robotnicza. Oskarżała ona biskupów o godzenie w rację bytu państwa polskiego ${ }^{26}$. Partia była zdumiona, a zarazem niezadowolona z postawy władz kościelnych. Niezadowolenie władz najwyższych związane było z przekroczeniem przez Kościół pewnej granicy. Partia prowadziła jedyną zgodną do zaakceptowania politykę

24 E.K. Czaczkowska, op. cit., s. 539.

25 P. Madajczyk, Okoliczności powstania Orędzia biskupów polskich do biskupów niemieckich, [w:] Wokół Orędzia. Kardynał Bolesław Kominek prekursor pojednania polsko-niemieckiego, red. W. Kucharski, G. Strauchold, Wrocław 2009, s. 119.

26 P. Raina, Kardynał Wyszyński. Orędzie Biskupów a reakcja władz, Warszawa 1995, s. 13. 
zagraniczną, a list do niemieckich biskupów był pewnego rodzaju przerwaniem partyjnego monopolu na stosunki zagraniczne ${ }^{27}$. Szybko zdano sobie sprawę, że należy zaatakować Kościół z całej siły i wszystkimi możliwymi sposobami, tak, by kler raz na zawsze stracił szacunek i zaufanie ludu pracującego. Władze PZPR zainicjowały walkę totalną z Kościołem, prowadzona była w początkowym okresie głównie przez środki masowego przekazu, jakim była prasa. Gazety ogólnopaństwowe takie jak „Życie Warszawy”, „Słowo Powszechne” i „Trybuna Ludu” oraz gazety lokalne jak wrocławskie „Słowo Polskie” czy „Gazeta Robotnicza” - podjęły próbę zdyskredytowania Kościoła i osoby Stefana Wyszyńskiego ${ }^{28}$. W swoich działaniach aparat propagandy uciekał się do zniekształceń tekstu Orędzia biskupów polskich do biskupów niemieckich, jak również przedstawiania fałszywych listów biskupich. Z czasem wielu uczonych i sławnych osób zaczęło angażować się w publiczne ataki na Kościół katolicki. Wśród nich były takie osobistości jak Aleksander Gieysztor, Konstanty Grzybowski, czy Juliusz Bardach ${ }^{29}$. Także inni wybitni uczeni i sportowcy jak prof. Karol Maleczyński, doc. Marian Orzechowski, Michał Szczepan czy Antoni Dąsal $^{30}$. Orędzie było pewnego rodzaju szansą, którą PZPR dostała, by zniechęcić ludzi do Kościoła, a tym samym zwiększyć poparcie społeczne dla działań władz państwowych. Biuro Polityczne Komitetu Centralnego PZPR poleciło podjąć szeroką akcję propagandową, mającą na celu oczernianie Kościoła i jego hierarchów $^{31}$. List biskupów zapoczątkował pewien okres działań antykościelnych znanych jako „Bitwa Milenijna”. Wynikiem tychże działań było m.in. niewpuszczenie do Polski papieża Pawła VI, który miał uczestniczyć i przewodzić duchowo obchodom „Tysiąclecia Chrztu Polski”. Kardynałowi Stefanowi Wyszyńskiemu nie zezwolono na wyjazd do Rzymu, a obchody Milenium zagłuszane były przez państwowe obchody „Tysiąclecia Państwa Polskiego”32. Służba Bezpieczeństwa 20 czerwca 1966 r. dokonała zatrzymania kopii obrazu Matki Boskiej Częstochowskiej, co powszechnie uznaje się za jeden z najbardziej barbarzyńskich momentów kampanii antykościelnej okresu „Bitwy Milenijnej”33.

27 S. Krzyżanowski, Kampania propagandowa $w$ sprawie orędzia biskupów polskich do biskupów niemieckich z 1965 roku w świetle prasy z Wrocławia i Zielonej Góry, [w:] In Gremium. Studia nad Historia, Kulturą i Polityką, Zielona Góra 2010, s. 155.

28 Ibidem, s. 148.

29 Ł. Kamiński, Władze PRL i społeczeństwo polskie wobec Orędzia biskupów polskich, [w:] Wokół Orędzia, s. 135.

30 Oficjalna strona portalu Nowe Życie, http://www.nowezycie.archidiecezja.wroc.pl/index.php/2015 /11/30/reakcja-komunistycznych-wladz-polski-na-oredzie-biskupow-polskich-do-biskupow-niemieckich (24.08.2021).

31 Ł. Kamiński, op. cit., s. 133.

32 Oficjalna strona portalu Tygodnik Powszechny, https://www.tygodnikpowszechny.pl/milenijnaproba-sil-156844 (24.08.2021).

33 Oficjalna strona portalu Wielka Historia, https://wielkahistoria.pl/dlaczego-polscy-komunisci-aresztowali-obraz-matki-boskiej-czestochowskiej (24.08.2021). 
Dnia 22 grudnia 1965 r. kierownictwo Departamentu Prasy i Informacji Ministerstwa Spraw Zagranicznych skierowało do swoich placówek stwierdzenie, że „Kierownictwo oceniło list jako zakrojoną na szeroką skalę dywersję polityczną" - Departament stwierdził, iż „język biblijny maskuje wrogie nam treści polityczne i ma nadawać manewrowi politycznemu Wyszyńskiego charakter religijnego przesłania”. Należy zaznaczyć, iż odpowiedzialność za słowa Orędzia wziął na siebie Episkopat Polski i kierujący nim kard. Stefan Wyszyński. To głównie na jego barki spadła najostrzejsza fala krytyki ze strony rządowej. Oprócz Prymasa ciężar krytyki przyjąć musiał także główny autor i inicjator listu biskupów abp Bolesław Kominek. Represje wobec niego nasiliły się po wydaniu Orędzia do tego stopnia, iż wyodrębniono grupę tajnych współpracowników, którzy oprócz ogólnej inwigilacji środowiska kościelnego we Wrocławiu mieli bacznie przyglądać się samemu arcybiskupowi ${ }^{34}$. W 1965 r. pojawił się szczególnie istotny problem, jaki napotkał Kościół w Polsce. Były nim działania rządowe dotyczące punktów katechetycznych, budownictwa sakralnego oraz zasadniczej służby wojskowej seminarzystów, odmowy wydawania paszportów dla duchowieństwa, jak również przejmowanie majątku kościelnego przez państwo. Kościół po raz pierwszy odniósł się do zarzutów kierowanych przez partię wobec hierarchów kościelnych 15 grudnia 1965 r. Wtedy to Episkopat Polski $\mathrm{w}$ wydanym komunikacie odrzucił wszystkie zarzuty KC PZPR i ich aparatu propagandy ${ }^{35}$. Wszystkim antyklerykalnym działaniom prawno-administracyjnym towarzyszyła stale ostra propaganda. Rok 1965 przyniósł również widoczną radykalizację społeczeństwa, w tym wzrost działań antyklerykalnych. Przykładem tych działań były chociażby wypraszanie osób duchownych z pociągów, liczne pogróżki czy nawet ataki słowne wobec kleru. Dość często zdarzały się także napaści fizyczne na księży czy braci zakonnych. Dnia 14 stycznia 1966 r. doszło do wystąpienia pierwszego sekretarza Władysława Gomułki. Podczas swojego wystąpienia odniósł się do treści Orędzia biskupów polskich do biskupów niemieckich. Stwierdził wtedy, że hierarchowie kościelni użyli niefortunnych sformułowań w treści listu. Zaledwie parę miesięcy później Władysław Gomułka 17 kwietnia 1966 r. w Poznaniu stwierdził

Jakże ograniczony i wyzbyty narodowego poczucia państwowości musi być umysł przewodniczącego episkopatu polskiego, który z tych tragedii, które spotkały Polskę, wyciąga taki tylko wniosek, że naród polski mógł [bardzo często być i bez króla i bez wodza i bez zwierzchników, i bez premierów i bez ministrów, ale naród ten nigdy nie żył bez pasterza]. Ten wojujący z naszym państwem ludowym nieodpowiedzialny pasterz, który głosi że nie będzie się korzył przed polską

34 S.A. Bogaczewicz, Działania resortu bezpieczeństwa wobec ks. Kard. Bolesława Kominka w latach 1945-1974. Zarys zagadnienia, [w:] Wokół Orędzia, s. 73.

35 Ł. Kamiński, op. cit., s. 134. 
racją stanu, stawia sobie swoje urojone pretensje do duchownego zwierzchnictwa nad narodem polskim wyżej niż niepodległość Polski ${ }^{36}$.

Władysław Gomułka chciał, by Kościół był podporządkowany partii, że powinien być instytucją państwową. Według pierwszego sekretarza jedynie partia miała prawo przemawiać w imieniu Polski i Polaków, więc gdy zrobił to Kościół to doszło do ostrej, a czasami agresywnej nagonki ze strony obozu rządzącego na swoich przeciwników. W okresie po Orędziu Prezydia Wojewódzkich Rad Narodowych zapraszały biskupów polskich na przesłuchania w sprawie treści Orędzia i tego, co biskupi uważają o jego przesłaniu. Osoby przesłuchujące hierarchów miały odgórnie przygotowaną listę z pytaniami do kleru ${ }^{37}$.

Jednym z istotnych przykładów działań państwowych wobec Prymasa było pismo Urzędu Rady Ministrów do biskupa Zygmunta Choromańskiego w sprawie odmowy na wyjazd za granicę kardynała Stefana Wyszyńskiego z dnia 7 stycznia 1966 r. MW-9/66. Tekst zawierał uzasadnienie odmowy wydania pozwolenia na wyjazd za granicę, w którym władze PRL twierdziły, iż ze względu na działalność polityczną Prymasa Wyszyńskiego, która jest szkodliwa dla polskiej racji stanu oraz mogące narazić na szwank interesy Polski Ludowej odmawia się wydania paszportu ${ }^{38}$. Powołano się na art. 4 ust. 2. pkt 3 ustawy o paszportach, który mówił, iż organ właściwy może odmówić wydania paszportu osobie działającej na niekorzyść interesów $\mathrm{PRL}^{39}$.

W Aktach Wojewódzkich do spraw Wyznań znajduje się relacja Lubelskiego Wydziału do spraw Wyznań o spotkaniu z księżmi powiatu kraśnickiego z dnia 14 grudnia $1965 \mathrm{r}$. Według dokumentów wynika, iż podczas tego spotkania ani jeden z obecnych na nim księży nie wspomniał o Orędziu biskupów polskich do biskupów niemieckich ${ }^{40}$. Wyrazili natomiast deklarację lojalności wobec państwa ${ }^{41}$. Kierownik Wydziału do spraw Wyznań Stefan Zahor wspomniał, iż ks. Niedźwiński zapewnił w imieniu wszystkich obecnych księży, że duchowieństwo nie będzie naruszać prawa państwowego ${ }^{42}$. Sytuacja zwierzchników Kościoła różniła się diametralnie od sytuacji zwykłych księży posługujących w parafiach. Według Informacji Kieleckiego Wydziału do spraw Wyznań o nastrojach wśród księży i ludności kieleckiej z dnia 15 grudnia 1965 r. wynika, że wiadomość o Orędziu wywołała wśród szeregowego kleru duże zaskoczenie, ale także i zażenowanie. $\mathrm{W}$ dokumencie wskazane jest, iż duchowieństwo było

36 Oficjalna strona portalu Nowe Życie, http://www.nowezycie.archidiecezja.wroc.pl index.php/ 2015/11/30/reakcja-komunistycznych-wladz-polski-na-oredzie-biskupow-polskich-do-biskupowniemieckich (24.08.2021).

37 P. Raina, op. cit., s. 14.

38 Ibidem, s. 35.

39 Ustawa z dnia 17 czerwca 1959 r. o paszportach (Dz.U. 1959 nr 36, poz. 224).

40 P. Raina, op. cit., s. 61.

41 Ibidem.

42 Ibidem. 
przekonane że list biskupów nie przyniesie nic dobrego dla narodu polskiego ${ }^{43}$. Księża pracujący w parafiach, mający na co dzień kontakt $\mathrm{z}$ wiernymi, byli przekonani, że działania ich zwierzchników spotkają się z niezadowoleniem i oburzeniem społeczeństwa. Związani ślubami posłuszeństwa kapłani tłumaczyli sobie, że skoro sam Prymas Wyszyński jest orędownikiem pojednania polsko-niemieckiego to i oni powinni to zaakceptować i podporządkować się woli przełożonych. Znane są także przypadki, gdy księża wyrażali się niepochlebnie na temat możliwości pojednania się z byłym okupantem. Polskie społeczeństwo będące pod działaniem propagandy partyjnej dość często atakowało słownie osobę Prymasa, lecz także atakowało miejscowych proboszczów czy wikarych.

Orędzie biskupów polskich do biskupów niemieckich zostało przyjęte przez niemiecką prasę na ogół przychylnie. Przez pewien czas podejrzewano nawet, że biskupi współdziałali nieoficjalnie z rządem PRL, lecz szybko przekonano się, że jednak była to wyłączna inicjatywa Kościoła w Polsce. Na zachód od Polski list biskupi został przyjęty dość różnie. Sympatyzująca z komunistami włoska „Unita” odniosła się dość krytycznie do idei pojednania polsko-niemieckiego. Brytyjski „The Observer” natomiast pisał, iż list jest wspaniałym gestem polskiego kleru i epokowym momentem w relacjach pomiędzy zwaśnionymi narodami ${ }^{44}$. Parę dni po przedstawieniu polskiego Orędzia, 5 grudnia 1965 r. strona niemiecka wydała odpowiedź na polski gest pojednania ${ }^{45}$. W odpowiedzi Kościół niemiecki uznał winy swego narodu, lecz nie odniósł się do sprawy granicy zachodniej Polski. Polscy biskupi byli dość rozczarowani postawą niemieckiego kleru, czemu wyraz dał Stefan Wyszyński w 1970 r. Kościół w Polsce liczył, iż niemieccy hierarchowie uznają nowe granice Polski na Zachodzie, gdyż był to oprócz kwestii historycznych główny element wrogości pomiędzy narodami ${ }^{46}$. Kierownictwo Kościoła w Polsce było przekonane, że skoro Polacy, jako naród najbardziej poszkodowany przez niemieckie zbrodnie wyciąga rękę do pojednania to Niemcy zrobią to samo. Skoro my wybaczamy kwestie historyczne to oni powinni zaakceptować kwestie granic. Tak się jednak nie stało, lecz było to bardzo mocnym impulsem, który w 7 grudnia 1970 poskutkował akceptacją przez Niemcy Zachodnie granicy na Odrze i Nysie Łużyckiej.

\section{Wnioski}

Orędzie biskupów polskich do ich niemieckich braci w Chrystusowym urzędzie pasterskim znane potocznie jako list biskupów polskich do biskupów niemieckich, jest niewątpliwie przełomowym momentem $\mathrm{w}$ dziejach relacji

43 Ibidem, s. 63.

44 J. Żaryn, Episkopat Polski w drodze do Orędzia (1945-1965), [w:] Wokół Orędzia, s. 101.

45 Ibidem.

46 R. Żurek, Odpowiedź biskupów niemieckich na Orędzie biskupów polskich, [w:] Wokót Orędzia, s. 121-123. 
polsko-niemieckich. Kościół kierując się nauką Jezusa Chrystusa pokazał, że przebaczenie jest istotnym elementem relacji społecznych. W okresie powojennym Niemcy były utożsamiane z całym złem, jakie istnieje na świecie. Dla ludzi, którzy stracili bliskich na wojnie lub sami spotkali się z okrucieństwem niemieckich działań podczas okupacji, propozycja pojednania się z największym wrogiem była czymś nie do zaakceptowania. Naród polski, który bardzo ucierpiał w okresie II wojny światowej bardzo często szukał ratunku w Kościele i je znajdował. To właśnie jeszcze mocniej ugruntowało zaufanie społeczne do Kościoła. Orędzie biskupów polskich do biskupów niemieckich wystawiło to zaufanie na próbę, lecz Kościół przez wszystkie lata swego istnienia spotykał na swojej drodze większe przeszkody, z którymi dawał sobie radę. Z perspektywy czasu możemy śmiało stwierdzić ,że i tym razem Kościół zwycięsko wyszedł $\mathrm{z}$ tej batalii, gdyż zamierzony cel, jakim było polepszenie stosunków pomiędzy dwoma zwaśnionymi narodami został zrealizowany. Pomimo działań propagandowych KC PZPR, nie udało się podważyć autorytetu Kościoła, Prymasa Wyszyńskiego czy arcybiskupa Kominka, który parę lat po przygotowaniu orędzia dostąpił godności kardynalskiej.

\section{Bibliografia}

Antkowiak Z., Wrocław od A do Z, Wrocław 1991.

Bogaczewicz S.A., Działania resortu bezpieczeństwa wobec ks. kard. Bolesława Kominka w latach 1945-1974. Zarys zagadnienia, [w:] Wokót Orędzia. Kardynał Bolesław Kominek prekursor pojednania polsko-niemieckiego, red. W. Kucharski, G. Stranchold, Wrocław 2009.

Borodziej W. (red.), Polska wobec zjednoczenia Niemiec 1989-1991, Warszawa 1992.

Czaczkowska E.K., Kardynał Wyszyński. Biografia, Kraków 2013.

Dudek A., Wybrane czynniki historyczne wptywajace na politykę władz PRL, [w:] Polityka czy propaganda. PRL wobec historii, red. P. Skibiński, T. Wiścicki, Warszawa 2009.

Dudra S., Nitschke B. (red.), Mniejszości narodowe i etniczne w Polsce po II wojnie światowej, Kraków 2010.

Ewangelia wedlug św. Mateusza, [w:] Pismo Święte Nowego Testamentu.

Gelles R., Konsulaty we Wrocławiu, Wrocław 1996.

Jacobsen H.A, Tomala M., Warszawa-Bonn 1945-1991. Stosunki polsko-niemieckie. Analiza i Dokumenty, Warszawa1992.

Jankowiak S., Wysiedlenia Niemców z Polski po II wojnie światowej, „Pamięć i Sprawiedliwość" 2004, nr 2(6).

Jankowiak S., Wysiedlenie i emigracja ludności niemieckiej w polityce władz polskich w latach 1945-1970, Warszawa 2005. 
Kacprzak P., Polityka władz polskich wobec ludności niemieckiej w okresie funkcjonowania Ministerstwa Ziem Odzyskanych, „Czasopismo Prawno-Historyczne” 2010, t. 62, z. 2.

Kamiński Ł., Władze PRL i społeczeństwo polskie wobec Orędzia biskupów polskich, [w:] Wokół Orędzia. Kardynał Bolesław Kominek prekursor pojednania polsko-niemieckiego, red. W. Kucharski, G. Stranchold, Wrocław 2009.

Kotula A. (red.), Przyjaźń nakazana? Stosunki między NRD i Polska w latach 1949-1990, Szczecin 2003.

Krzyżanowski S., Kampania propagandowa w sprawie orędzia biskupów polskich do biskupów niemieckich z 1965 roku w świetle prasy z Wrocławia i Zielonej Góry, [w:] In Gremium. Studia nad Historia, Kulturą i Polityka, Zielona Góra 2010.

Madajczyk P., Okoliczności powstania Orędzia biskupów polskich do biskupów niemieckich, [w:] Wokół Orędzia. Kardynał Bolesław Kominek prekursor pojednania polsko-niemieckiego, red. W. Kucharski, G. Stranchold, Wrocław 2009.

Orędzie biskupów polskich do biskupów niemieckich. Materiały i dokumenty, Warszawa 1966.

Raina P., Kardynał Wyszyński. Orędzie Biskupów a reakcja władz, Warszawa 1995.

Rajfur M., Cały świat ustyszał, „Gość Niedzielny”, 29 listopada 2020.

Ranke A., Stosunki Polsko-Niemieckie w Polskiej publicystyce katolickiej w latach 1945-1989, Toruń 2004.

Skubiszewski K., Wysiedlenie Niemców po II wojnie światowej, Warszawa 1968.

Żaryn J., Episkopat Polski w drodze do Orędzia (1945-1965), [w:] Wokół Orędzia. Kardynał Bolesław Kominek prekursor pojednania polsko-niemieckiego, red. W. Kucharski, G. Stranchold, Wrocław 2009.

Żurek R., Odpowiedź biskupów niemieckich na Orędzie biskupów polskich, [w:] Wokół Orędzia. Kardynał Bolesław Kominek prekursor pojednania polsko-niemieckiego, red. W. Kucharski, G. Stranchold, Wrocław 2009.

Oficjalna strona portalu Wielka Historia, https://wielkahistoria.pl/dlaczego-polscy-komunisci-aresztowali-obraz-matki-boskiej-czestochowskiej

Oficjalna strona portalu Tygodnik Powszechny, https://www.tygodnikpowszechny.pl/milenijna-proba-sil-156844

Oficjalna strona portalu Nowe Życie, http://www.nowezycie.archidiecezja.wroc.pl/index. php/2015/11/30/reakcja-komunistycznych-wladz-polski-na-oredzie-biskupow-polskich-do-biskupow-niemieckich

\section{STRESZCZENIE}

W niniejszej pracy ukazano rolę Orędzia biskupów polskich do biskupów niemieckich w unormowaniu wzajemnych relacji polsko-niemieckich. Poruszona w pracy została kwestia relacji między dwoma zwaśnionymi narodami przed wydaniem listu, jak również pracę nad treścią samego Orędzia. Przedstawiono w tekście istotę problemu wzajemnych relacji , jakim była kwestia historycznej odpowiedzialności za zbrodnie na narodzie polskim. Poza tym poruszona została kwestia przesiedleń 
ludności niemieckiej z terenów przyłączonych do Polski po wojnie, a także kwestie granicy zachodniej Polski na Odrze i Nysie Łużyckiej. Tekst zawiera dokładne przedstawienie prac nad treścią Orędzia, a także reakcję papieża Pawła VI na działania hierarchów kościelnych. Oprócz dość szczegółowego opisu prac związanych z powstaniem Orędzia biskupów polskich do niemieckich, przedstawione zostały także reakcje społeczne na treść listu, zarówno społeczeństwa polskiego i niemieckiego. Przedstawiono w tekście działania propagandowe władz Polskiej Rzeczpospolitej Ludowej wobec Kościoła katolickiego w Polsce, a także poruszono problem braku akceptacji części społeczeństwa polskiego dla poczynań hierarchów kościelnych. Reakcja na treść listu biskupów została także przedstawiona z perspektywy państw zachodniej Europy. Gest pojednania i brak odpowiedniego odzewu ze strony niemieckiej, oraz wpływ działań biskupów na unormowanie, a z czasem i nawiązanie poprawnych relacji pomiędzy państwami. Zostały one poruszone i omówione w artykule. Opisano w nim istotę listu biskupów oraz jego wpływ na dalsze losy narodu polskiego i niemieckiego.

\section{SUMMARY}

\section{Letter of Reconciliation of the Polish Bishops to the German Bishops as a Step Towards Normalizing Polish-German Relations}

This work presents the role of the message of Polish bishops to German bishops in regulating mutual Polish-German relations. The issue of the relationship between the two feuding nations before the publication of the letter was discussed, as well as the work on the content of the letter itself. The text presents the essence of the problem of mutual relations, which was the question of historical responsibility for crimes against the Polish nation. In addition, the issue of resettlement of the German population from the areas annexed to Poland after the war was raised, as well as the issue of the western border of Poland on the Odra and Nysa Łużycka rivers. The text contains a detailed presentation of the work on the content of the message, as well as the reaction of Pope Paul VI to the actions of church hierarchs. In addition to a fairly detailed description of the works related to the creation of the letter of Polish bishops to German, there were also presented social reactions to the content of the letter, both of Polish and German society. The text presents the propaganda activities of the Polish People's Republic authorities towards the Catholic Church in Poland, as well as the problem of the lack of acceptance of a part of Polish society for the actions of church hierarchs. The reaction to the content of the bishops' letter was also presented from the perspective of Western European countries. A gesture of reconciliation and the lack of an appropriate response from the German side, and the impact of bishops' actions on the normalization and, over time, the establishment of correct relations between states. They were touched upon and discussed in the above work. The work describes the essence of the bishops' letter and its impact on the further fate of the Polish and German nation. 